\title{
DAMPAK PENIADAAN PARALEGAL TERHADAP PERLINDUNGAN HUKUM KEPADA KELOMPOK MASYARAKAT MISKIN (PUTUSAN MAHKAMAH AGUNG REPUBLIK INDONESIA NOMOR 22 P/HUM/2018)
}

\author{
Jeffri Pri, ${ }^{1}$ Edwin Tunggawan, ${ }^{2}$ Kennedy Kenny ${ }^{3}$ \\ ${ }^{1}$ Fakultas Hukum, Universitas Tarumanagara Jakarta \\ E-mail: Jeffmartono@gmail.com \\ ${ }^{2}$ Fakultas Hukum, Universitas Tarumanagara Jakarta \\ E-mail:edwins.tunggawan@gmail.com \\ ${ }^{3}$ Fakultas Hukum, Universitas Tarumanagara Jakarta \\ E-mail: kennedyknny@gmail.com
}

\begin{abstract}
Providing legal assistance is a form of state responsibility for poor community groups as a manifestation of access to justice. This is a guarantee from the state to every person in order to gain recognition, guarantee, protection and legal certainty as a form of protection of human rights. The provision of legal assistance is a state obligation as ordered by the legislation stated in Article 54 of the Constitution of Republic of Indonesia Number 8 of 1981 concerning Criminal Code Procedure (hereinafter referred to as the Book of Constitution of Criminal Code Procedure / KUHAP), even reemphasized as mandatory in Article 56 of the KUHAP. However, the provision of legal assistance currently does not reach all Indonesian citizens due to the limited implementation of legal assistance itself. In effort to solve these limitations, the role of paralegals was brought forth to increase the provision of legal assistance to the poor. Post-emergence of the Decision of the Supreme Court of the Republic of Indonesia Number 22 P / HUM / 2018 which cancels the role of paralegals stated in the Regulation of the Minister of Law and Human Rights of the Republic of Indonesia Number 01 of 2018 concerning Paralegals in the Provision of Legal Aid has affected poor communities seeking justice. In this case the role of an advocate as an honorable profession which, in carrying out his/her profession, must be brought forward and moreover, it is an obligation in carrying out orders both from the constitution or the code of ethics for the advocate profession in order to provide free assistance after the removal of Article 11 and Article 12 Permenkumham On Paralegal, which has actually been previously regulated in Article 22 of the Advocate Law.
\end{abstract}

Keywords: provision of legal assistance, poor community groups, advocates.

\begin{abstract}
ABSTRAK
Pemberian bantuan hukum merupakan bentuk tanggung jawab negara bagi kelompok masyarakat miskin sebagai perwujudan kepada akses keadilan. Hal ini merupakan jaminan dari negara terhadap setiap orang dalam rangka mendapatkan pengakuan, jaminan, perlindungan, dan kepastian hukum sebagai bentuk perlindungan dari pada hak asasi manusia. Pemberian bantuan hukum merupakan suatu kewajiban negara sebagaimana hal ini diperintahkan oleh peraturan perundang-undangan yang dinyatakan dalam Pasal 54 Undang-Undang Republik Indonesia Nomor 8 Tahun 1981 tentang Hukum Acara Pidana (selanjutnya disebut dengan Kitab Undang-Undang Hukum Acara Pidana/KUHAP), bahkan ditekankan lagi sebagai hal yang wajib adanya dalam Pasal 56 KUHAP. Akan tetapi pemberian bantuan hukum saat ini belum menjangkau seluruh masyarakat Indonesia dikarenakan adanya keterbatasan pelaksanaan bantuan hukum itu sendiri. Dalam hal mengisi keterbatasan tersebut dimunculkan peran paralegal untuk meningkatkan pemberian bantuan hukum terhadap kelompok masyarakat miskin. Pasca munculnya Putusan Mahkamah Agung Republik Indonesia Nomor 22 P/HUM/2018 yang membatalkan peran dari pada paralegal yang dinyatakan dalam Peraturan Menteri Hukum dan Hak Asasi Manusia Republik Indonesia Nomor 01 Tahun 2018 tentang Paralegal Dalam Pemberian Bantuan Hukum telah memberikan dampak terhadap kelompok masyarakat miskin dalam mencari keadilan. Dalam hal ini peran advokat sebagai profesi terhormat yang dalam menjalankan profesinya harus dimunculkan dan apalagi hal tersebut merupakan suatu kewajiban dalam menjalankan perintah baik dari pada undang-undang maupun kode etik profesi advokat dalam rangka memberikan bantuan secara cuma-cuma setelah dicabutnya Pasal 11 dan Pasal 12 Permenkumham Tentang Paralegal, yang sebenarnya telah diatur sebelumnya dalam Pasal 22 UU Advokat.
\end{abstract}

Kata kunci: pemberian bantuan hukum, kelompok masyarakat miskin, advokat.

\section{PENDAHULUAN}


Negara Republik Indonesia sebagai negara hukum berdasarkan Pancasila dan Undang-Undang Dasar Negara Republik Indonesia Tahun 1945 (selanjutnya disebut dengan UUD NRI 1945), bertujuan untuk mewujudkan tata kehidupan bangsa yang sejahtera, aman, tenteram, tertib dan adil. Hal ini secara tegas dinyatakan dalam Pasal 1 Ayat (3), yang menyatakan Negara Indonesia adalah negara hukum. Prinsip negara hukum menuntut antara lain adanya jaminan kesederajatan bagi setiap orang di hadapan hukum (equality before the law) (Pasal 27 ayat (1) UUD 1945). Oleh karena itu UUD NRI 1945 juga menentukan bahwa setiap orang berhak atas pengakuan, jaminan, perlindungan dan kepastian hukum yang adil serta perlakuan yang sama dihadapan hukum.

Untuk mewujudkan prinsip-prinsip negara hukum dalam kehidupan berbangsa dan bernegara diperlukan adanya penegakan hukum yang merupakan rangkaian langkah aparat penegak hukum melakukan penindakan hukum terhadap tiap pelanggaran yang terjadi (Parera, 2016). Menurut Soerjono Soekanto, dalam proses penegakan hukum itu sendiri, selalu melibatkan sejumlah faktor atau unsur yang saling terkait satu sama lain, yakni faktor hukum; faktor aparat penegak hukum; faktor sarana atau fasilitas yang mendukung penegakan hukum; dan faktor budaya (Soekanto, 1986). Hal ini juga dinyatakan oleh Shidarta bahwa penegakan hukum itu sendiri merupakan suatu sistem yang kompleks, hukum itu merupakan sistem yang mana sistem tersebut terdiri dari unsur-unsur tersendiri (Shidarta, 2009). Melalui penegakan hukum, aparat penegak hukum menjalankan tugas profesinya demi tegaknya keadilan yang berdasarkan hukum, termasuk usaha memberdayakan masyarakat dalam menyadari hak-hak fundamental mereka di depan hukum. Dengan perkataan lain, apapun kondisi yang dipersepsikan terhadap profesi hukum, profesi ini secara intrinsik tetap merupakan profesi luhur yang dibutuhkan oleh masyarakat, bangsa, dan Negara (Shidarta, 1996).

Sebagai negara yang menjunjung tinggi hukum dalam kehidupan berbangsa dan bernegara, Negara Kesatuan Republik Indonesia (NKRI) menjamin hak konstitusional setiap orang untuk mendapatkan pengakuan, jaminan, perlindungan, dan kepastian hukum yang adil serta perlakuan yang sama di hadapan hukum sebagai sarana perlindungan hak asasi manusia. Selain itu negara juga bertanggung jawab terhadap pemberian bantuan hukum bagi orang miskin (Badan Pusat Statistik, 2018) sebagai perwujudan akses terhadap keadilan. Hal ini merupakan perwujudan dari Pasal 34 UUD NRI 1945, yang menyatakan bahwa fakir miskin dan anak-anak yang terlantar dipelihara oleh negara. Selain itu juga hal ini terkait sebagai perwujudan dari pada Pasal 28D Ayat (1) UUD NRI 1945, yang menyatakan setiap orang berhak atas pengakuan, jaminan, perlindungan, dan kepastian hukum yang adil serta perlakuan yang sama di hadapan hukum.Hal ini merupakan bentuk penghormatan kepada kemanusiaan ataupun kepada jaminan dan perlindungan hak asasi manusia (HAM) dan warga Negara (Nugraha, 2013).

Pemberian bantuan hukum diatur dalam Undang-Undang Republik Indonesia Nomor 16 Tahun 2011 Tentang Bantuan Hukum (selanjutnya disebut dengan UU Bantuan Hukum), yang merupakan sebagai bentuk pertanggung jawaban dari pada negara terhadap pemberian bantuan hukum bagi orang miskin sebagai perwujudan akses terhadap keadilan. Adapun hal ini juga tidak bisa dilepaskan dari pada profesi advokat itu sendiri sebagai salah satu pilar dalam menegakkan supremasi hukum dan hak asasi manusia dengan menjalankan tugas profesinya demi tegaknya keadilan yang didasarkan atas hukum untuk kepentingan masyarakat pencari keadilan.Terutama dalam pemberian bantuan hukum secara cuma-cuma bagi orang miskin yang merujuk kepada Pasal 22 Undang-Undang Republik Indonesia Nomor 18 Tahun 2003 Tentang Advokat (selanjutnya disebut dengan UU Advokat).

Bantuan hukum bagi para pencari keadilan merupakan suatu kewajiban kepada negara untuk melakukan hal itu, sebagaimana hal ini diperintahkan oleh peraturan perundang-undangan, dalam hal ini adalah Pasal 54 Undang-Undang Republik Indonesia Nomor 8 Tahun 1981 Tentang Hukum Acara Pidana (selanjutnya disebut dengan Kitab Undang-Undang Hukum Acara 
Pidana/KUHAP), yang menyatakan bahwa guna kepentingan pembelaan, tersangka atau terdakwa berhak mendapat bantuan hukum dari seorang atau lebih penasihat hukum selama dalam waktu dan pada setiap tingkat pemeriksaan, menurut tata cara yang ditentukan dalam undang-undang ini. Bahkan hal ini ditekankan lagi sebagai hal yang wajib adanya dalam Pasal 56 KUHAP yang menyatakan sebagai berikut:

1) Dalam hal tersangka atau terdakwa disangka atau didakwa melakukan tindak pidana yang diancam dengan pidana mati atau ancaman lima belas tahun atau lebih atau mereka yang tidak mampu yang diancam dengan pidana lima tahun atau lebih yang tidak mempunyai penasihat hukum sendiri, pejabat yang bersangkutan pada semua tingkat pemeriksaan dalam proses peradilan wajib menunjuk penasihat hukum bagi mereka.

2) Setiap penasihat hukum yang ditunjuk untuk bertindak sebagaimana dimaksud dalam ayat 1 memberikan bantuannya dengan cuma-cuma.

Sedemikian pentingnya hal tersebut, konsekuensi hukum tidak dilaksanakannya pendampingan bagi tersangka oleh penasihat hukum adalah tidak dapat diterimanya dakwaan Penuntut Umum, hal ini sudah menjadi yurisprudensi tetap Mahkamah Agung Republik Indonesia dalam putusannya No. 1565 K/Pid/1991, tertanggal 16 September 1993 yang menyatakan bahwa penyidikan yang melanggar Pasal 56 ayat 1 KUHAP menyebabkan hasil penyidikan tidak sah sehingga dakwaan Jaksa Penuntut Umum tidak dapat diterima (Yurisprudensi Mahkamah Agung, 1993).

Terkait dengan proses bantuan hukum terhadap para pencari keadilan yang tidak mampu, putusan Mahkamah Agung Republik Indonesia Nomor 22 P/HUM/2018 yang memeriksa dan mengadili perkara permohonan keberatan hak uji materiil terhadap Peraturan Menteri Hukum dan Hak Asasi Manusia Republik Indonesia Nomor 01 Tahun 2018 Tentang Paralegal dalam Pemberian Bantuan Hukum, Berita Negara Republik Indonesia Nomor 182 Tahun 2018 pada tingkat pertama dan terakhir telah memutuskan bahwa menyatakan Pasal 11 dan Pasal 12 Peraturan Menteri Hukum dan Hak Asasi Manusia Nomor 01 Tahun 2018 Tentang Paralegal (selanjutnya disebut dengan Permenkumham Tentang Paralegal) dalam pemberian Bantuan Hukum bertentangan dengan peraturan perundang-undangan yang lebih tinggi, yaitu UndangUndang Republik Indonesia Nomor 18 Tahun 2003 Tentang Advokat dan memerintahkan kepada Menteri Hukum dan Hak Asasi Manusia Republik Indonesia untuk mencabut Pasal 11 dan Pasal 12 Permenkumham Tentang Paralegal tersebut.

\section{Rumusan Masalah}

Berdasarkan hal tersebut di atas, tim penulis tertarik melakukan kajian mengenai perlindungan hukum terhadap para pencari keadilan dari kalangan orang miskin pasca adanya putusan Mahkamah Agung Republik Indonesia Nomor 22 P/HUM/2018.

\section{PEMBAHASAN}

Hak atas bantuan hukum telah diterima secara universal yang dijamin dalam Kovenan Internasional tentang Hak-Hak Sipil dan Politik (International Covenant on Civil and Political Rights (ICCPR)). Pasal 16 dan Pasal 26 ICCPR menjamin semua orang berhak memperoleh perlindungan hukum serta harus dihindarkan dari segala bentuk diskriminasi. Pasal 14 Ayat (3) ICCPR, memberikan syarat terkait bantuan hukum, yaitu: (a) kepentingan-kepentingan keadilan, dan (b) tidak mampu membayar advokat.

Secara konvensional di Indonesia sejak dahulu bantuan hukum diartikan sebagai bantuan yang diberikan oleh seorang pembela/pengacara terhadap kilennya baik dalam perkara pidana maupun 
perkara perdata di muka persidangan. Istilah ini baru popular sejak adanya Undang-Undang Republik Indonesia Nomor 19 Tahun 1964 tentang Ketentuan-Ketentuan Pokok Kekuasaan Kehakiman yang secara tegas mengatur masalah bantuan hukum (Abdurrahman, 1982). Akan tetapi maksud dari pada bantuan hukum ini bukanlah bantuan hukum terhadap orang miskin sebagaimana hal ini dinyatakan dalam Pasal 4 Ayat (3) undang-undang ini, bahwa dalam perkara perdata pengadilan membantu dengan sekuat tenaga para pencari keadilan dan berusaha sekeraskerasnya supaya segala hambatan dan rintangan untuk peradilan yang cepat, sederhana, dan murah, disingkirkan.

Ketentuan Pasal 1 ayat (1) UU Bantuan Hukum menyebutkan bahwa bantuan hukum adalah jasa hukum yang diberikan oleh pemberi bantuan hukum secara cuma-cuma kepada penerima bantuan hukum, yakni orang atau kelompok orang miskin, dan yang dimaksud dengan pemberi bantuan hukum adalah lembaga bantuan hukum atau organisasi kemasyarakatan yang memberi layanan bantuan hukum berdasarkan undang-undang ini. Kedua hal tersebut tercantum dalam Pasal 1 Ayat 2 dan 3 UU Bantuan Hukum. Undang-undang ini menyatakan bahwa bantuan hukum dilaksanakan berdasarkan asas keadilan; persamaan kedudukan dalam hukum; keterbukaan; efisiensi; efektivitas; dan akuntabilitas. Menurut Adnan Buyung Nasution, bantuan hukum adalah khusus bantuan hukum bagi golongan masyarakat berpenghasilan rendah atau dalam bahasa popular adalah si miskin (Nasution, 1988). Adapun yang dinyatakan oleh Soerjono Soekanto tentang bantuan hukum adalahbantuan hukum (baik yang berbentuk pemberian nasihat hukum, maupun yang berupa menjadi kuasa dari pada seseorang yang berperkara) yang diberikan kepada orang yang tidak mampu ekonominya, sehingga ia tidak dapat membayar biaya (honorarium) kepada seorang pembela atau pengacara (Soekanto, 1983).

Penerima bantuan hukum adalah mereka yang tidak mampu secara sosial-ekonomis-politis maupunn yang buta hukum (Soekanto, 1983). Ketetapan MPR Nomor II/MPR/1983, menyatakan bahwa penyelenggaraan dan pemberian bantuan hukum tertuju pada lapisan masyarakat yang kurang mampu. Pasal 4 UU Bantuan Hukum menyatakan bahwa bantuan hukum diberikan kepada penerima bantuan hukum yang sedang menghadapi permasalahan hukum, dalam hal ini bantuan hukum yang dimaksud meliputi masalah hukum keperdataan, pidana, dan tata usaha negara baik litigasi maupun nonlitigasi. Bantuan hukum kepada orang miskin tersebut meliputi menjalankan kuasa, mendampingi, mewakili, membela, dan atau melakukan tindakan hukum lain untuk kepentingan hukum penerima bantuan hukum.Sejalan dengan hal tersebut, bantuan hukum merupakan salah satu upaya dalam mengisi hak asasi manusia terutama bagi lapisan rakyat termiskin (Lubis, 1986).Hal ini sejalan dengan Pasal 5 Ayat (1) UU Bantuan Hukum yang menyatakan bahwa penerima bantuan hukum sebagaimana dimaksud dalam Pasal 4 Ayat (1) meliputi setiap orang atau kelompok orang miskin yang tidak dapat memenuhi hak dasar secara layak dan mandiri. Hak dasar yang dimaksud dalam hal ini mengacu kepada ayat (2) dari pada pasal 5 UU Bantuan Hukum ini, yakni meliputi hakatas pangan, sandang, layanan kesehatan, layanan pendidikan, pekerjaan dan berusaha, dan atau perumahan.

Seminar nasional mengenai Arti dan Peningkatan Pemberian Bantuan Hukum yang diselenggarakan oleh Fakultas Hukum Universitas Indonesia, bantuan hukum dikaitkan dengan Darma Ketiga Perguruan Tinggi yang dilakukan dengan jalan:

1. Memberikan konsultasi hukum serta jasa-jasa lain yang berhubungan dengan hukum.

2. Memberikan penyuluhan terhadap masyarakat khususnya kepada pencari hukum untuk menjunjung tinggi norma-norma hukum.

3. Memberikan bantuan hukum secara aktif dan langsung secara merata kepada masyarakat, khususnya kepada pencari hukum. 
Sejalan dengan hal tersebut di atas, sebagaimana tercantum dalam Pasal 9 UU Bantuan Hukum, menyatakan bahwa pemberi bantuan hukum berhak:

a. Melakukan rekrutmen terhadap advokat, paralegal, dosen dan mahasiswa fakultas hukum;

b. Melakukan pelayanan bantuan hukum;

c. Menyelenggarakan penyuluhan hukum, konsultasi hukum, dan program kegiatan lain yang berkaitan dengan penyelenggaraan bantuan hukum;

d. Menerima anggaran dari negara untuk melaksanakan pelayanan bantuan hukum;

e. Mendapatkan informasi dan data lain dari pemerintah ataupun instani lain untuk kepentingan pembelaan perkara; dan

f. Mendapatkan jaminan perlindungan hukum, keamanan, dan keselamatan selama menjalankan pemberian bantuan hukum.

Berdasarkan pemahaman dari pada penulis yang berhak dalam memberikan bantuan hukum adalah advokat, paralegal, dosen dan mahasiswa fakultas hukum. Sehubungan dengan itu, definisi dari pada advokat merujuk kepada UU Advokat dalam Pasal 1 ayat (1) yang menyatakan bahwa advokat adalah orang yang berprofesi memberi jasa hukum, baik di dalam maupun di luar pengadilan yang memenuhi persyaratan berdasarkan ketentuan undang-undang ini. Ketika memberikan bantuan hukum, pemberi bantuan hukum tidak dapat dituntut secara perdata maupun pidana dalam memberikan bantuannya, sebagaimana hal ini dinyatakan dalam Pasal 11 UU Bantuan Hukum. Hal ini sejalan dengan prinsip dari pada hak imunitas profesi advokat sebagaimana tercantum dalam Pasal 16 UU Advokat yang menyatakan bahwa advokat tidak dapat dituntut baik secara perdata maupun pidana dalam menjalankan tugas profesinya dengan itikad baik untuk kepentingan pembelaan klien dalam sidang pengadilan. Adapun Putusan Mahkamah Konstitusi Nomor 26/PUU-XI/2003 telah memperluas makna dari pada hak imunitasi tersebut, menyatakan bahwa advokat tidak dapat dituntut baik secara perdata maupun pidana dalam menjalankan tugas profesinya dengan itikad baik (Pasal 16 UU Advokat) untuk kepentingan pembelaan klien di dalam maupun di luar sidang pengadilan.

Terkait dengan bantuan hukum yang dilakukan dalam rangka memberikan bantuan hukum terhadap orang miskin dan buta hukum, ada yang disebut dengan paralegal, sebagaimana hal tersebut diatur dalam Permenkumham tentang Paralegal. Peraturan menteri tersebut tidak merumuskan definisi paralegal secara jelas, akan tetapi dalam Pasal 2 Permenkumham tentang Paralegal menyatakan bahwa paralegal diatur dalam peraturan menteri ini merupakan paralegal yang melaksanakan pemberian bantuan hukum dan terdaftar pada pemberi bantuan hukum. Dalam Pasal 3 Permenkumham Tentang Paralegal menyatakan sebagai berikut:

1) Pemberi bantuan hukum memberikan bantuan hukum secara litigasi dan nonlitigasi kepada penerima bantuan hukum (Pasal 1 ayat (1) dan (1) UU Bantuan Hukum.

2) Dalam memberikan bantuan hukum, pemberi bantuan hukum berhak melakukan rekrutmen paralegal sebagai pelaksana bantuan hukum.

3) Pemberi bantuan hukum dapat merekrut paralegal di luar pelaksana bantuan hukum yang telah terdaftar jika:

a. Ketersediaan jumlah pelaksana bantuan hukum tidak mencukupi dalam menangani perkara dan atau

b. Tidak terdapat pemberi bantuan hukum di wilayah tempat tinggal penerima bantuan.

Black's Law Dictionary, memberikan penjelasan tentang paralegal sebagai (1) someone who has some education in law and assist a lawyer in duties related to the practice of law but who is not a licensed attorney. (2) Canadian law. A non-lawyer who is legally qualified through experience or special training and is licensed to provide limited legal services in certain fields. Paralegals 
may assist in representing clients both civil and criminal matters. Batasan tersebut merumuskan paralegal sebagai seseorang yang memiliki pendidikan tentang ilmu hukum dan membantu advokat didalam praktik hukum dan sudah memiliki pengalaman dan pelatihan khusus untuk melayani pelayanan hukum secara terbatas dalam bidang-bidang tertentu baik dalam perdata maupun pidana.

Merujuk kepada Permenkumham tentang Paralegal bahwa paralegal harus memenuhi persayaratan sebagaimana tercantum dalam Pasal 4 Permenkumham Tentang Paralegal, sebagai berikut:
a. Warga negara Indonesia;
b. Berusia paling rendah 18 (delapan belas) tahun;
c. Memiliki pengetahuna tentang advokasi masyarakat dan atau
d. Memenuhi syarat lain yang ditentukan oleh pemberi bantuan hukum.

Selanjutnya dalam Pasal 5 Permenkumham Tentang Paralegal bahwa sebagai berikut:

1) Paralegal yang telah terdaftar pada pemberi bantuan hukum memperoleh kartu identitas yang diterbitkan oleh pemberi bantuan hukum.

2) Kartu identitas sebagaimana dimaksud ada ayat (2) berlaku paling lama 2 (dua) tahun dan dapat diperpanjang.

3) Pemberi bantuan hukum mendaftarkan paralegal sebagai pelaksana bantuan hukum kepada BPHN melalui sistem informasi database bantuan hukum.

Paralegal berhak atas pelatihan paralegal dalam rangka meningkatkan kualifikasi paralegal dalam memberikan bantuan hukum sebagaimana hal ini tercantum dalam Pasal 6 Permenkumham Tentang Paralegal. Adapun kualifikasi yang dimaksud mengacu dalam Pasal 6 Ayat (3) Permenkumham Tentang Paralegal meliputi:

a. Kemampuan memahami kondisi wilayah dan kelompok-kelompok kepentingan dalam masyarakat;

b. Kemampuan melakukan penguatan masyarakat dalam memperjuangkan hak asasi manusia, dan hak-hak lain yang dilindungi oleh hukum; dan

c. Keterampilan mengadvokasi masyarakat berupa pembelaan dan dukungan terhadap masyarakat lemah untuk mendapatkan haknya.

Pelatihan paralegal itu sendiri sebagaimana dinyatakan dalam Pasal 7 Permenkumham Tentang Paralegal, diselenggarakan oleh:

a. Pemberi bantuan hukum;

b. Perguruan tinggi;

c. Lembaga swadaya masyarakat yang memberikan bantuan hukum; dan atau

d. Lembaga pemerintah yang menjalankan fungsinya di bidang hukum.

Pasal 7 Ayat (2) Permenkumham Tentang Paralegal menyatakan bahwa dalam menyelenggarakan pelatihan paralegal, penyelenggara dapat bekerja sama dengan pemerintah, pemerintah daerah atau pihak terkait lainnya.Selanjutnya Pasal 11 Permenkumham Tentang Paralegal menyatakan, paralegal dapat memberikan bantuan hukum secara litigasi dan nonlitigasi setelah terdaftar pada pemberi bantuan hukum dan mendapatkan sertifikat pelatihan paralegal tingkat dasar. Sebagaimana disebutkan dalam Pasal 12 Permenkumham Tentang Paralegal bahwa Pemberian bantuan hukum secara litigasi oleh paralegal dilakukan dalam bentuk pendampingan advokatpada lingkup pemberi bantuan hukum yang sama. Adapun pendampingan itu meliputi:

a. Pendampingan dan atau menjalankan kuasa yang dimulai dari tingkat penyidikan, dan penuntutan; 
b. Pendampingan dan atau menjalankan kuasa dalam proses pemeriksaan di persidangan; atau

c. Pendampingan dan atau menjalankan kuasa terhadap penerima bantuan hukum di pengadilan tata usaha negara.

Ketentuan UU Advokat, Pasal 1 Ayat (1) yang menyatakan bahwa advokat adalah orang yang berprofesi memberi jasa hukum, baik di dalam maupun di luar pengadilan yang memenuhi persyaratan berdasarkan ketentuan undang-undang ini. Jasa hukum yang dimaksudkan sebagaimana dalam Pasal 1 Ayat (2) UU Advokat adalah jasa yang diberikan advokat berupa memberikan konsultasi hukum, bantuan hukum, menjalankan kuasa, mewakili, mendampingi, membela, dan melakukan tindakan hukum lain untuk kepentingan hukum klien. Dalam Pasal 1 huruf a Kode Etik Advokat Indonesia (selanjutnya disebut dengan Kode Etik Advokat) menyatakan bahwa advokat adalah orang yang berpraktek memberi jasa hukum, baik didalam, maupun di luar pengadilan yang memenuhi persyaratan berdasarkan undang-undang yang berlaku, baik sebagai advokat, pengacara, penasehat hukum, pengacara praktek ataupun sebagai konsultan hukum.

Berdasarkan Kamus Hukum Black, advokat ataupun pengacara atau lawyer didefinisikan sebagai someone who assists, defends, pleads, or prosecutes for another.Kamus tersebut membedakan definisi lawyer, dengan someone who, having been licensed to practice law, is qualified to advise people about legal matters, prepare contracts and other legal instruments. And represent people in court. Menurut Harlen Sinaga, berdasarkan pemaparan hal tersebut, cakupan advokat meliputi mereka yang melakukan pekerjaan baik di pengadilan maupun di luar pengadilan, sebagaimana diatur dalam UU Advokat, dan juga sebagai politik hukum (legal policy) apabila dilihat dari sudut ilmu hukum sebagaimana pernyataan pendapat dari Purnadi Purbacaraka dan Soerjono Soekanto (Sinaga, 2011).

Sama seperti pemberi bantuan hukum, termasuk paralegal bahwa advokat juga mempunyai hak imunitas dalam menjalankan profesinya sebagaimana hal ini tercantum dalam Pasal 16 UU Advokat dan perluasannya melalui Putusan Mahkamah Konstitusi Nomor 26/PUU-XI/2003 telah memperluas makna dari pada hak imunitasi tersebut, terkait dengan penambahan frasa di dalam maupun di luar pengadilan. Pasal 11 UU Bantuan Hukum menyatakan hal yang sama dengan itu, yakni pemberi bantuan hukum tidak dapat dituntut secara perdata maupun pidana dalam memberikan bantuan.

Advokat dalam menjalakan profesinya harus didasarkan pada persayaratan yang harus dipenuhi seperti dalam Pasal 2 Ayat (1) dan (2) UU Advokat yang menyatakan bahwa yang dapat diangkat menjadi advokat adalah sarjana yang berlatar belakang pendidikan tinggi hukum (Penjelasan Pasal 1 ayat (2) UU Advokat) dan setelah mengikuti pendidikan khusus profesi advokat yang dilakukan oleh organisasi advokat, dan juga pengangkatan advokat dilakukan oleh organisasi advokat. Selanjutnya pada ketentuan Pasal 3 Ayat (1)UU Advokat dinyatakan bahwa untuk dapat diangkat menjadi advokat harus memenuhi persyaratan sebagai berikut:
a. Warga negara Republik Indonesia;
b. Bertempat tinggal di Indonesia;
c. Tidak berstatus sebagai pegawai negeri atau pejabat negara;
d. Berusia sekurang-kurangnya 25 (dua puluh lima) tahun;
e. Berijazah sarjana yang berlatar belakang pendidikan tinggi hukum sebagaimana dimaksud dalam Pasal 2 ayat 1
f. Mengikuti pendidikan khusus profesi advokat;
g. Lulus ujian yang diadakan oleh organisasi advokat;
h. Magang sekurang-kurangnya 2 (dua) tahun terus menerus pada kantor advokat; 
i. Tidak pernah dipidana karena melakukan tindak pidana kejahatan yang diancam dengan pidana penjara 5 (lima) tahun atau lebih;

j. Berprilaku baik, jujur, bertanggung jawab, adil, dan mempunyai integritas yang tinggi.

Advokat merupakan penegak hukum, bebas dan mandiri yang dijamin oleh hukum dan peraturan perundang-undangan dengan wilayah kerja yang meliputi seluruh wilayah negara Republik Indonesia sebagaimana dinyatakan dalam Pasal 5 ayat 1 dan 2 UU Advokat. Menurut penjelasan Pasal 5 Ayat 1 UU Advokat frasa advokat berstatus sebagai penegak hukum adalah advokat sebagai salah satu perangkat dalam proses peradilan yang mempunyai kedudukan setara dengan penegak hukum lainnya dalam menegakkan hukum dan keadilan. Adapun kata bebas dapat diartikan dengan mengacu pada penjelasan Pasal 14 UU Advokat yang adalah tanpa tekanan, ancaman, hambatan, tanpa rasa takut, atau perlakuan yang merendahkan harkat dan martabat profesi. Kebebasan tersebut dilaksanakan sesuai dengan kode etik profesi dan peraturan perundang-undangan.

Selain memperoleh honorarium atas jasa hukum yang telah diberikan kepada kliennya sebagaimana tercantum dalam Pasal 21 UU Advokat, ada suatu kewajiban yang harus dilakukan oleh advokat sebagaimana dinyatakan dalam Pasal 22 UU Advokat, sebagai berikut:

1) Advokat wajib memberikan bantuan hukum secara cuma-cuma kepada pencari keadilan yang tidak mampu;

2) Ketentuan mengenai persyaratan dan tata cara pemberian bantuan hukum secara cumacuma sebagaimana dimaksud pada ayat (1), diatur lebih lanjut dengan Peraturan Pemerintah, dalam hal ini Peraturan Pemerintah Republik Indonesia Nomor 83 Tahun 2008 Tentang Persyaratan dan Tata Cara Pemberian Bantuan Hukum Secara Cuma-Cuma (selanjutnya disebut dengan PP Bantuan Hukum).

Terkait dengan pemberian bantuan hukum secara cuma-cuma, Pasal 12 PP Bantuan hukum menyatakan sebagai berikut:

1) Advokat dilarang menolak permohonan bantuan hukum secara cuma-cuma;

2) Dalam hal terjadi penolakan pemberian bantuan hukum sebagaimana dimaksud pada ayat 1, pemohon dapat mengajukan keberatan kepada organisasi advokat atau lembaga bantuan hukum yang bersangkutan.

Hal ini wajib dilakukan oleh advokat dan apabila dilanggar akan mendatangkan suatu konsekuensi hukum sebagaimana diatur dalam Pasal 14 PP Bantuan Hukum, sebagai berikut:

1. Advokat yang melanggar ketentuan sebagaimana dimaksud dalam Pasal 12 dan Pasal 13 dijatuhi sanksi oleh organisasi advokat.

2. Sanksi berupa sebagaimana dimaksud pada ayat (1) dapat berupa:

a. Teguran lisan;

b. Teguran tertulis;

c. Pemberhentian sementara dari profesinya selama 3 (tiga) sampai dengan 12 (dua belas) bulan berturut-turut; atau

d. Pemberhentian tetap dari profesinya.

3. Sebelum advokat dikenai tindakan sebagaimana dimaksud pada ayat (1), kepada yang bersangkutan diberikan kesempatan untuk melakukan pembelaan diri.

4. Ketentuan mengenai tata cara pembelaan diri dan penjatuhan sanksi sebagaimana dimaksud pada ayat (1) dilakukan sesuai dengan ketentuan yang berlaku dalam organisasi advokat.

Sejalan dengan ketentuan-ketentuan yang telah dijelaskan sebelumnya, dalam Pasal 7 huruf h Kode Etik Advokat bahwa advokat mempunyai kewajiban untuk memberikan bantuan hukum secara cuma-cuma (pro deo) bagi orang yang tidak mampu. Hal ini merupakan perintah dari 
pada Kode Etik Advokat tersebut dan akan menimbulkan akibat hukum apabila hal ini tidak dilakukan. Selanjutnya Pasal 9 Kode Etik Advokat menyatakan bahwa:

a. Setiap advokat wajib tunduk dan mematuhi Kode Etik Advokat ini.

b. Pengawasan atas pelaksanaan Kode Etik Advokat ini dilakukan oleh Dewan Kehormatan. Adapun dengan dewan kehormatan sebagaimana dimaksud dalam Pasal 10 ayat 1 Kode Etik Advokat, bahwa dewan kehormatan berwenang memeriksa dan mengadili perkara pelanggaran kode etik yang dilakukan advokat.

Advokat sebagai posisi terhormat (officium nobile) yang dalam menjalankan profesinya berada di bawah perlindungan hukum, undang-undang dan kode etik, memiliki kebebasan yang didasarkan kepada kehormatan dan kepribadian advokat yang berpegang teguh pada kemandirian, kejujuran, kerahasiaan, dan keterbukaan. Oleh karenan itu setiap advokat harus menjaga citra dan martabat kehormatan profesi, serta setia dan menjunjung tinggi kode etik dan sumpah profesi yang pelaksanaannya diawasi oleh Dewan Kehormatan sebagai suatu lembaga yang eksistensinya telah dan harus diakui oleh setiap advokat tanpa melihat dari organisasi profesi yang mana ia berasal dan menjadi anggota yang pada saat mengucapkan sumpah profesinya tersirat pengakuan dan kepatuhannya terhadap kode etik advokat yang berlaku. Terkait dengan kode etik advokat diatur dalam Pasal 33 UU Advokat yang menyatakan bahwa kode etik dan ketentuan tentang Dewan Kehormatan Profesi Advokat yang telah ditetapkan oleh Ikatan Advokat Indonesia (IKADIN), Asosiasi Advokat Indonesia (AAI), Ikatan Penasihat Hukum Indonesia (IPHI), Himpunan Advokat dan Pengacara Indonesia (HAPI), Serikat Pengacara Indonesia (SPI), Asosisasi Konsultan Hukum Indonesia (AKHI), dan Himpunan Konsultan Hukum Pasar Modal (HKHPM), pada tanggal 23 Mei 2002 dinyatakan mempunyai kekuatan hukum secara mutatis mutandis menurut undang-undang ini sampai ada ketentuan yang baru yang dibuat oleh organisasi advokat.

Terkait akan hal ini adanya beberapa advokat yang melakukan uji materiil terhadap Peraturan Menteri Hukum dan Hak Asasi Manusia Republik Indonesia Nomor 01 Tahun 2018 Tentang Paralegal Dalam Pemberian Bantuan Hukum, Berita Negara Republik Indonesia Nomor 182 Tahun 2018 (Permenkumham Tentang Paralegal) terhadap peraturan perundang-undangann yang lebih, yaitu Undang-Undang Negara Republik Indonesia Nomor 18 Tahun 2003 Tentang Advokat (UU Advokat), Lembaran Negara Republik Indonesia Tahun 2003 Nomor 49. Uji materiil ini dilakukan di Mahkamah Agung Republik Indonesia (Pasal 24 A UUD 1945). Para advokat tersebut ialah Bireven Aruan, S.H.; Johan Imanuel, S.H.; Marta Dinata, S.H.; Abdul Jabbar, S.H.I.; Irwan Gustaf Lalegit, S.H.; Ika Arini Batubara, S.H.; Denny Supari, S.H.; Liberto Julihartama, S.H.; Steven Albert, S.H.; Abdul Salam, S.H.; Ade Anggraini, S.H.; Arnol Sinaga, S.H.; Asep Dedi, S.H.; Indra Rusmi, S.H.; Fista Sambuari, S.H.; Alvin Maringan, S.H.; Teuku Muttaqin, S.H.; Endin, S.H.; yang selanjutnya disebut sebagai Para Pemohon, yang dalam hal ini melawan Menteri Hukum Dan Hak Asasi Manusia Republik Indonesia, yang selanjutnya disebut sebagai Termohon.

Para Pemohon dengan surat permohonannya tertanggal 2 April 2018 yang diterima Kepaniteraan Mahkamah Agung pada tanggal 9 April 2018 dan di register nomor 22 P/HUM/2018 telah mengajukan permohonan keberatan hak uji materiil terhadap Permenkumham Tentang Paralegal. Adapun yang mereka dalilkan diajukannya uji materiil (judicial review) terhadap Permenkumham Tentang Paralegal sebagai berikut:

1. Permenkumham Tentang Paralegal telah menimbulkan keresahan di kalangan advokat; Bahwa paralegal merupakan asisten advokat dalam praktek beracara atau litigasi di negara-negara maju seperti Inggris dan Amerika, justru di Indonesia dengan terbitnya Permenkumham Tentang Paralegal memiliki kedudukan layaknya profesi advokat. 
Mereka menilik dari definisi paralegal di negara-negara maju seperti Inggris dan Amerika Serikat, seperti definisi paralegal dalam Organisasi National Association of Licensed Paralegals Inggris Raya; American Bar Association (BAR); From The National Federation of Paralegals Association (NFPA); Organisasi National Association of Legal Assistants (NALA); American Association For Paralegal Education (AAFPE). Sehingga menimbulkan keresahan bagi advokat di saat seorang paralegal di Indonesia beracara di muka pengadilan tanpa memiliki latar belakang pendidikan minimal sarjana hukum sebagaimana diatur dalam Pasal 4 huruf c Permenkumham tentang Paralegal. Akan tetapi tidak ada penjelasan dalam pasal lainnya mengenainya pengetahuan tentang advokasi masyarakat dalam Permenkumham Tentang Paralegal seperti apa? Sehingga rentan terjadi kekeliruan disaat proses beracara di persidangan baik secara teknis maupun administrative disaat seorang paralegal yang berdiri sendiri berhadapan dengan seorang advokat.

Selama ini agar seorang pengacara dapat beracara di peradilan Indonesia maka seseorang tersebut harus terlebih dahulu telah memiliki latar belakang pendidikan tinggi ilmu hukum sebagaimana disyaratkan dalam Pasal 3 UU Advokat.

2. Permenkumham Tentang Paralegal dapat mengacaukan tatanan sistem pendidikan hukum beracarapada peradilan Indonesia;

Atas dasar ketentuan Pasal 7 ayat 1 huruf (c) Permenkumham Tentang Paralegal, dalam ringkasannya menyatakan bahwa lembaga swadaya masyarakat dapat memberikan bantuan hukum. Frasa tersebut jelas membuat kabur, membingungkan dan tidak jelas tentang pelatihan bagi paralegal dimana paralegal yang dapat dilatih oleh Lembaga Swadaya Masyarakat (LSM) dikarenakan selama ini dalam tatanan sistem adalah 2 (dua) hal yang berbeda antara Lembaga Swadaya Masyarakat dan Lembaga bantuan Hukum yakni:

a. Lembaga Swdaya Masyarakat (LSM) dalam tujuannya dalah sebagai penggiat organisasi sosial bagi masyarakat;

b. Lembaga Bantuan Hukum (LBH) dalam tujuannya adalah suatu badan/organisasi yang memberikan bantuan dalam bentuk keilmuan profesi hukum.

Bagaimana mungkin LSM yang merupakan suatu badan/organisasi yang membrikan bantuan sosial akan memberikan pelatihan-pelatihan ilmu hukum dan tata beracara dalam peradilan Indonesia.

3. Permenkumham tentang Paralegal berpotensi menimbulkan kebingungan dan ketidakpastian dalam masyarakat serta diduga mengambilalih kedudukan profesi advokat;

Hal ini terkait dengan Pasal 11 dan Pasal 12 Permenkumham Tentang Paralegal. Hal tersebut menyebabkan kedudukan paralegal sama seperti advokat sehingga Permenkumham Tentang Paralegal jelas bertolak belakang dan diduga ada penyelundupan kedudukan profesi advokat melalui Permenkumham Tentang Paralegal yang dapat diambilalih oleh paralegal.

4. Permenkumham Tentang Paralegal dinilai cacat hukum;

Permenkumham Tentang Paralegal ini tidak berdasar dan cacat hukum karena telah melanggar asas/prinsip hukum lex superior derogate lex inferiori yang artinya peraturan perundang-undangan yang lebih tinggi mengesampingkan peraturan perundang-undangan yang lebih rendah, dari muatan materi yang diaturnya dapat dikatakan cacat hukum karena bertentangan dengan UU Advokat.

5. Permenkumham Tentang Paralegal patut diduga menyamakan dirinya dengan pengadilan tinggi di Indonesia; 
Pasal 10 Permenkumham Tentang Paralegal dapat diduga telah mensejajarkan diri penyelenggaraan pelatihan paralegal dengan pengadilan tinggi di Indonesia karena berdasarkan UU Advokat, seorang yang hendak beracara dalam peradilan di Indonesia harus terlebih dahulu disumpah oleh pengadilan tinggi diseluruh Indonesia dan diberikan berita acara sumpah.

Padapertimbangannya, majelis hakim agung menyatakan bahwa Pasal 4 huruf b dan c serta Pasal 7 ayat (1) huruf c Permenkumham Tentang Paralegal, tidak melanggar asas lex superior derogate lex inferiori, sebab hal tersebut tidak bertentangan dengan UU Advokat. Adapun dalam Pasal 11 dan 12 Permenkumham Tentang Paralegal memuat norma yang memberikan ruang dan kewenangan kepada paralegal untuk dapat beracara dalam proses pemeriksaan persidangan di pengadilan. Ketentuan tersebut dapat dimaknai paralegal menjalankan sendiri proses pemeriksaan persidangan di pengadilan, dan bukan hanya mendampingi atau membantu advokat. Ketentuan normatif mengenai siapa yang dapat beracara dalam proses pemeriksaan persidangan di pengadilan telah diatur di dalam Pasal 4 juncto 31 UU Advokat, yang pada pokoknya hanya advokat yang telah bersumpah di sidang terbuka pengadilan tinggi yang dapat menjalankan profesi advokat untuk dapat beracara dalam proses pemeriksaan persidangan di pengadilan.

Dengan demikian muatan materi Pasal 11 dan Pasal 12 Permenkumham Tentang Paralegal bertentangan dengan UU Advokat, sehingga demikian melanggar asas lex superior derogate lex inferiori. Oleh karena itu terbukti bahwa Pasal 11 dan Pasal 12 Permenkumham Tentang Paralegal bertentangan dengan peraturan yang lebih tinggi yaitu UU Advokat, sehingga harus dibatalkan, dan oleh karenanya permohonan keberatan hak uji materiil dari pemohon harus dikabulkan sebagian dan Pasal 11 dan Pasal 12 Permenkumham Tentang Paralegal yang menjadi objek dalam perkara aquo harus dibatalkan sehingga tidak mempunyai kekuatan hukum mengikat untuk umum.

Atas dasar rapat permusyawaratan majelis hakim pada hari Kamis, tanggal 31 Mei 2018, oleh Dr. Irfan Fachruddin, S.H., C.N. Hakim Agung yang ditetapkan oleh Ketua Mahkamah Agung sebagai ketua majelis, bersama-sama dengan Dr. Yosran, S.H., M.Hum., dan Is Sudaryono, S.H., M.H., Hakim Agung sebagai anggota dan diucapkan dalam sidang terbuka untuk umum pada hari itu juga oleh ketua majelis beserta hakim-hakim anggota tersebut dan Adi Irawan, S.H., M.H., Panitera Pengganti tanpa dihadiri oleh para pihak. Dalam hal tersebut Majelis Hakim Agung mengabulkan keberatan hak uji materiil dari para pemohon dengan menyatakan Pasal 11 dan Pasal 12 Permenkumham tentang Paralegal bertentangan dengan peraturan perundangundangan yang lebih tinggi, yaitu UU Advokat dan karenanya tidak berlaku umum, serta memerintahkan kepada Menteri Hukum dan Hak Asasi Manusia Republik Indonesia untuk mencabut Pasal 11 dan Pasal 12 Permenkumham Tentang Paralegal.

Dengan dicabutnya Pasal 11 Permenkumham Tentang Paralegal, yang menyatakan paralegal dapat memberikan bantuan hukum secara litigasi dan nonlitigasi setelah terdaftar pada pemberi bantuan hukum dan mendapatkan sertifikat pelatihan paralegal tingkat dasar. Serta Pasal 12 Permenkumham tentang Paralegal, yang menyatakan sebagai berikut:

1) Pemberian bantuan hukum secara litigasi oleh paralegal dilakukan dalam bentuk pendampingan advokat pada lingkup pemberi bantuan hukum yang sama.

2) Pendampingan sebagaimana dimaksud pada ayat (1) meliputi:

a. Pendampingan dan atau menjalankan kuasa yang dimulai dari tingkat penyidikan dan penuntutan;

b. Pendampingan dan atau menjalankan kuasa dalam proses pemeriksaan di persidangan; atau

c. pendampingan dan atau menjalankan kuasa terhadap penerima bantuan di Pengadilan Tata Usaha Negara. 
3) Pendampingan advokat sebagimana dimaksud pada ayat (1) dibuktikan dengan surat keterangan pendampingan dari advokat yang memberikan bantuan hukum.

Munculnya putusan Mahkamah Agung yang memutuskan untuk mencabut Pasal 11 dan Pasal 12 Permenkumham Tentang Paralegal, mengakibatkan paralegal tidak dapat memberikan bantuan hukum baik secara litiagsi maupun nonlitigasi selain itu juga tidak dapat lagi dapat melakukan pendampingan dan atau menjalankan kuasa baik itu dalam tahapan penyidikan, penuntutan, dan dalam pemeriksaan di sidang pengadilan. Dikarenakan yang dapat melakukan hal itu semua adalah seorang yang berprofesi sebagai advokat yang sebagaimana telah melewati dan telah memenuhi berbagai persyaratan yang ada dalam UU Advokat.

Terkait dengan perlindungan hukum bagi orang miskin atas dicabutnya Pasal 11 dan Pasal 12 Permenkumham Tentang Paralegal telah memberi kewenangan yang luas kepada advokat, dikarenakan tidak ada lagi profesi tandingan yang dapat meresahkan para advokat sebagaimana hal tersebut tercantum dalam salah satu hal yang didalilkan dalam melakukan uji materiil antara Permenkumham Tentang Paralegal dengan UU Advokat. Dalam hal ini seorang advokat harus dapat mengetahui dengan pasti bahwa dengan dicabutnyanya kedua pasal tersebut, advokat harus melaksanakan kewajibannya sebagaimana diatur dalam UU Advokat terkait dengan pemberian bantuan hukum secara cuma-cuma atau prodeo, sebagaimana hal tersebut diatur dalam Pasal 22 UU Advokat yang menyatakan sebagai berikut:

1) Advokat wajib memberikan bantuan hukum secara cuma-cuma kepada pencari keadilan yang tidak mampu.

2) Ketentuan mengenai persyaratan dan tata cara pemberian bantuan hukum secara cumacuma sebagaimana dimaksud dalam ayat (1), diatur lebih lanjut dengan Peraturan Pemerintah.

Yang dimaksud dengan frasa diatur lebih lanjut dengan Peraturan Pemerintah adalah Peraturan Pemerintah Republik Indonesia Nomor 83 Tahun 2008 Tentang Persyaratan dan Tata Cara Pemberian Bantuan Hukum Secara Cuma-Cuma (PP Bantuan Hukum). Pasal 1 Ayat (3)PP Bantuan Hukum menyatakan bantuan hukum secara cuma-cuma adalah jasa yang diberikan advokat tanpa menerima pembayaran honorarium meliputi pemberian konsultasi hukum, menjalankan kuasa, mewakili, mendampingi, membela, dan melakukan tindakan hukum lain untuk kepentingan pencari keadilan yang tidak mampu. Selanjutnya dalam Pasal 1 Ayat (3) PP Bantuan Hukummendefinisikan pencari keadilan yang tidak mampu sebagai orang perseorangan atau sekelompok orang yang secara ekonomis tidak mampu yang memerlukan jasa hukum advokat untuk menangani dan menyelesikan masalah hukum.PP Bantuan Hukum juga mewajibkan kepada advokat untuk memberikan bantuan hukum secara cuma-cuma kepada pencari keadilan, sebagaimana diatur adalam Pasal 2 dan juga dalam Pasal 12 Ayat (1) PP Bantuan Hukum bahwa advokat dilarang menolak permohonan bantuan hukum secara cumacuma.Pada Kode Etik Advokat juga diatur hal yang serupa dengan PP Bantuan hukum tersebut yakni dalam Pasal 7 huruf h, menyatakan bahwa advokat mempunyai kewajiban untuk memberikan bantuan hukum sceara cuma-cuma (pro deo) bagi orang yang tidak mampu.

Sejalan kewajiban tersebut, bahwa bilamana advokat tidak melaksanakan kewajibannya tersebut itu maka akan mendatangkan suatu konsekuensi hukum sebagaimana tercantum dalam Pasal 14 PP Bantuan Hukum, yang berisi:

1) Advokat yang melanggar ketentuan sebagaimana dimaksud dalam Pasal 12 dan Pasal 13 dijatuhi sanksi oleh organisasi advokat.

2) Sanksi sebagaimana dimaksud pada ayat (1) dapat berupa:

a) Teguran lisan;

b) Teguran tertulis; 
c) Pemberhentian sementara dari profesinya selama 3 (tiga) sampai dengan 12 (dua belas) bulan berturut-turut; atau pemberhentian tetap dari profesinya.

3) Sebelum advokat dikenai tindakan sebagaimana dimaksud dalam ayat (1), kepada yang bersangkutan diberikan kesempatan untuk melakukan pembelaan diri.

4) Ketentuan mengenai tata cara pembelaan diri dan penjatuhan sanksi sebagaimana pada ayat 1 dijatuhkan sesuai dengan ketentuan yang berlaku dalam organisasi advokat.

Hal yang perlu diingat bahwa Setiap advokat diangkat dan disumpah sebelum menjalankan profesinya.Sumpahini menjadi benteng sikap advokat dalam melaksanakan profesinya.Tanggung jawab advokat adalah memberikan jasa hukum, baik kepada orang yang mampu maupun kepada yang tidak mampu, sehingga pelanggaran pelanggaran terhadap tanggung jawab itu merupakan pelanggaran terhadap sumpah advokat (Waldemar, 2008).

\section{KESIMPULAN DAN SARAN}

Advokat sebagai profesi terhormat (officium nobile) yang dalam menjalankan profesinya berada di bawah perlindungan hukum, undang-undang dan kode etik, memiliki kebebasan yang didasarkan kepada kehormatan dan kepribadian advokat yang berpegang teguh kepada kemandirian, kejujuran, kerahasiaan, dan keterbukaan.Hal ini seperti apa yang dinyatakan oleh O.C. Kaligis, yang menyatakan bahwa legal profession is a very noble profession. Oleh karenanya sesuatu yang telah ditentukan atau diwajibkan sebagaimana baik oleh peraturan perundang-undangan yang berlaku maupun kode etik profesi haruslah dilaksanakan sebaikbaiknya. Advokat harus dapat mempunyai empati yang mendalam terhadap kaum miskin dan teraniaya yang tidak mempunyai akses kepada hukum.Dalam hal inilah etika dalam menjalankan sebuah profesi hukum dari pada advokat diuji. Maka dari itu apa yang diwajibkan dalam undangundang maupun kode etik profesi advokat harus dilaksanakan sebaik mungkin, terlebih lagi akan mendatangkan suatu konsekuensi apabila hal tersebut tidak dilakukan, sebagaimana hal tersebut telah dinyatakan dalam peraturan perundang-undangan maupun dalam kode etik profesi advokat itu sendiri. Hal ini sendiri dilaksanakan agar setiap orang baik miskin maupun kaya mempunyai hak yang sama dihadapan hukum sebagaimana hal ini merupakan amanat yang diamanatkan Pasal 27 ayat (1) UUD NRI, yang berbunyi segala warga Negara bersamaan kedudukannya di dalam hukum dan pemerintahan dan wajib menjunjung hukum dan pemerintahan itu dengan tidak ada kecualinya.

Bahwa adalah suatu kewajiban dalam menjalankan perintah baik dari pada undang-undang maupun kode etik profesi advokat dalam rangka memberikan bantuan secara cuma-cuma setelah dicabutnya Pasal 11 dan Pasal 12 Permenkumham Tentang Paralegal, yang sebenarnya telah diatur sebelumnya dalam Pasal 22 UU Advokat. Sejalan dengan hal tersebut bahwa pengawasan atas pelaksanaan kode etik advokat harus dilakukan lebih serius dan lebih mendalam oleh Dewan Kehormatan sebagaimana hal ini tercantum dalam Pasal 9 huruf b Kode Etik Advokat, yang juga dimana Dewan Kehormatan juga berwenang memeriksa dan mengadili pelanggaran kode etik yang dilakukan oleh advokat, sebagaimana hal ini terdapat dalam Pasal 10 ayat (1) Kode Etik Advokat. Adapun hal yang sama juga dinyatakan dalam Pasal 14 PP Bantuan Hukum, yang menyerahkan pertanggungjawaban dalam rangka penindakan kepada organisasi advokat bilamana ada advokat yang melanggar ketentuan-ketentuan yang bersifat kode etik sebagaimana hal tersebut dinyatakan dalam ketentuan yang berlaku.Sejalan dengan itu bahwa advokat memiliki kode etik yang ditetapkan oleh organisasi advokat.Kode etik ini berlaku mengikat advokat sebagai dasar sikap dan tindakan advokat dalam menjalankan profesinya.Maka dari pada itulah seorang advokat harus dapat memahami fungsinya sebagai seorang yang menjiwai profesi advokat itu sendiri, yaitu dimana advokat wajib menjalankan profesinya dengan tidak melanggar kode etik profesinya sebagai penegak hukum yang bebas, dan mandiri. 


\section{UCAPAN TERIMA KASIH.}

Penulis mengucapkan terima kasih kepada semua pihak. Tanpa mengurangi rasa hormat, kami tidak menyebutkan satu persatu, pihak yang tidak telah membantu dalam penulisan artikel ini.

\section{REFERENSI}

Abdurrahman. (1982). Aspek-aspek bantuan hukum di indonesia. Jakarta: Cendana Press.

Lubis, T. M. (1986). Bantuan hukum dan kemiskinan struktural. Jakarta: LP3ES.

Muhammad, A. K. (1997). Etika profesi hukum. Bandung: Citra Aditya Bakti.

Nasution, A. B. (1988). Bantuan hukum di indonesia. Jakarta: LP3ES.

Parera, T. Y. (2016). Advokat dan penegakan hukum. Yogyakarta: Genta Press.

Shidarta. (2009). Moralitas profesi hukum suatu tawaran kerangka berpikir. Bandung: Refika Aditama.

Sinaga, V. H. (2011). Dasar-dasar profesi advokat. Jakarta: Penerbit Erlangga.

Soekanto, S. (1983). Bantuan hukum suatu tinjauan sosio yuridis. Jakarta: Ghalia Indonesia.

Soekanto, S. (1986). Faktor-faktor yang mempengaruhi penegakan hukum. Jakarta: Rajawali. Indonesia, Undang-Undang Dasar Negara Republik Indonesia Tahun 1945.

Indonesia, Undang-Undang Republik Indonesia Nomor 19 Tahun 1964 Tentang KetentuanKetentuan Pokok Kekuasaan Kehakiman, Lembaran Negara Republik Indonesia (LNRI) Tahun 1964 Nomor 107, dan Tambahan Lembaran Negara (TLN) Nomor 2699.

Indonesia, Undang-Undang Republik Indonesia Nomor 8 Tahun 1981 Tentang Hukum Acara Pidana.

Indonesia, Undang-Undang Republik Indonesia Nomor 18 Tahun 2003 Tentang Advokat, Lembaran Negara Republik Indonesia (LNRI) Tahun 2003 Nomor 49, dan Tambahan Lembaran Negara (TLN) Nomor 4288.

Indonesia, Undang-Undang Republik Indonesia Nomor 16 Tahun 2011 Tentang Bantuan Hukum, Lembaran Negara Republik Indonesia (LNRI) Tahun 2011 Nomor 104, dan Tambahan Lembaran Negara (TLN) Nomor 5248.

International Covenant on Civil and Political Rights (ICCPR). Indonesia, Peraturan Pemerintah Republik Indonesia Nomor 83 Tahun 2008 tentang persyaratan dan tata cara pemberian bantuan hukum secara cuma-cuma. Indonesia, Peraturan Menteri Hukum dan Hak Asasi Manusia Republik Indonesia Nomor 01 Tahun 2018 Tentang Paralegal dalam Pemberian Bantuan Hukum. Indonesia, Kode Etik Advokat Indonesia.

Nugraha, D. P. (2013). Memaknai (kembali) empat pilar kehidupan berbangsa dan bernegara Indonesia", UPH Law Review Volume XII No. 3. Banten: Universitas Pelita Harapan.

Shidarta. (1996). Etika profesi hukum dalam sorotan. Era Hukum No. 9/Th. 3/Juli. Jakarta: Universitas Tarumanagara.

Waldemar, Ade. (2008). Fungsi Advokat Dalam Perkara Korupsi, ERA HUKUM No. 2/TH. 15/JANUARI. Jakarta: Universitas Tarumanagara.

Kaligis, O.C. (2008). Legal Profession and The Emerging Issues, ERA HUKUM No. 2/TH. 15/JANUARI: Universitas Tarumanagara.

Ramly Hutabarat dalam pidato pengukuhannya sebagai Guru Besar Hukum Tata Negara di Fakultas Hukum Universitas Indonesia pada tanggal 1 agustus 2007

Seminar Nasional "Arti dan Peningkatan Pemberian Bantuan Hukum" Oleh Fakultas Hukum Negeri pada tahun 1976 yang diselenggarakan oleh Fakultas Hukum Universitas Indonesia

(2014). Black's Law Dictionary Tenth Edition, United States of America: Thomson Reuters 
Kamus Besar Bahasa Indonesia.

Putusan Mahkamah Agung Republik Indonesia No. 1565 K/Pid/1991.

Putusan Mahkamah Agung Republik Indonesia Nomor 22 P/HUM/2018.

Putusan Mahkamah Konstitusi Nomor 26/PUU-XI/2003.

Ketetapan MPR Nomor II/MPR/1983.

https://www.bps.go.id/subject/23/kemiskinan-dan-ketimpangan.html 